\title{
EFIKASI DIRI DAN PERILAKU PERAWATAN DIRI PASIEN DIABETES MELITUS TIPE 2 DI WILAYAH PUSKESMAS PAHANDUT
}

\author{
Alfeus Manuntung \\ Poltekkes Kemenkes Palangka Raya \\ Jl. George Obos No. 30, 32, Menteng, Kec. Jekan Raya, Kota Palangka Raya, Kalimantan \\ Tengah, Indonesia \\ alfeusmanuntung@gmail.com
}

\begin{abstract}
Abstrak
Diabetes Melitus Tipe 2 memerlukan perawatan dan pengelolaan secara mandiri untuk mencegah komplikasi akut dan kronis. Tujuan penelitian ini yaitu menganalisis hubungan antara efikasi diri dan perawatan diri diabetesi di wilayah Puskemas Pahandut dan menggunakan rancangan penelitian deskriptif korelasi cross sectional. Teknik pengambilan sampel menggunakan consecutive sampling. Pengumpulan data efikasi diri menggunakan DMSES dan perilaku perawatan diri menggunakan SDSCA. Analisa data menggunakan uji Chi Square. Berdasarkan hasil penelitian diperoleh bahwa mayoritas responden DM Tipe 2 tingkat efikasi dirinya tinggi $(61,7 \%)$, sedangkan tingkat perilaku perawatan diri responden DM Tipe 2 rendah $(53,2 \%)$. Hasil analisis data Chi Kuadrat diperoleh ada hubungan antara efikasi diri dan perawatan diri diabetesi. Pendekatan perilaku dapat dilakukan untuk menurunkan angka komplikasi dan mengoptimalkan kualitas hidup diabetesi.
\end{abstract}

Kata Kunci: efikasi diri, perilaku perawatan diri, DM Tipe 2

\begin{abstract}
Type 2 Diabetes Mellitus requires treatment and management independently to stop acute and chronic complications. The aim of this study was to research correlation between self efficacy and diabetes self care behavior within the work area of the Pahandut Public Health Center with a correlational descriptive study design employing a cross sectional. The sampling technique used consecutive sampling. Data collection was done by identifying self efficacy and self-care behavior employing a questionnaire. Data analysis using Chi Square. The results showed that the absolute best level of efficacy of Type 2 DM respondents (61.7\%), while the extent of self-care of Type 2 DM respondents was low (53.2\%). Chi Square data analysis results obtained there's a relationship between self-efficacy and self-care behavior of Type 2 DM patients. Behavioral approaches are often wont to reduce the amount of complications and optimize the standard of lifetime of people with diabetes.
\end{abstract}

Keywords: self efficacy, self care behavior, Type 2 DM

\section{PENDAHULUAN}

Diabetes Melitus Tipe 2 paling sering terjadi sehingga memerlukan penatalaksanaan medis dan pengelolaan secara mandiri untuk mencegah komplikasi (ADA, 2010). Diabetes Melitus termasuk penyakit kronis serius dan salah satu dari penyakit tidak menular yang terjadi karena sel betha kurang mampu menghasilkan hormon insulin dan atau tidak dapat memanfaatkan hormon insulin untuk mengontrol gula darah secara efektif. Menurut data dari World Health Organization Global Report, 2016 angka kesakitan akibat penyakit Diabetes Melitus semakin bertambah dalam beberapa tahun. Pada tahun 2012 penyakit Diabetes Melitus menyebabkan angka mortalitas di dunia sebesar 1,5 juta jiwa dengan tambahan 2,2 juta kematian pada diabetesi dengan gula

Corresponding author:

Alfeus Manuntung

alfeusmanuntung@gmail.com 
darah yang melebihi angka normal. Kematian ini terjadi sebanyak $43 \%$ dari 3,7 juta jiwa pada diabetesi dengan usia di bawah 70 tahun. Negara miskin dan negara berkembang didapatkan angka mortalitas Diabetes Melitus lebih banyak terjadi.

Hasil laporan dari IDF tahun 2019 menyatakan bahwa terdapat 463 juta orang dewasa (20-79 tahun) menderita Diabetes Melitus, sekitar $10 \%$ dari pengeluaran kesehatan global dihabiskan untuk Diabetes Melitus sekitar 760 miliar USD. Penderita Diabetes Melitus sebanyak 79\% bermukim di beberapa negara dengan ekonomi rendah dan menengah didapatkan 2 dari 3 pengidap Diabetes Melitus tinggal di daerah perkotaan (310,3 juta) dan di Indonesia diperkirakan jumlah penderita DM semakin bertambah pada tahun 2015 dari 10 juta menjadi 16,2 juta di 2040.

Kemenkes pada tahun 2018 melaporkan bahwa Indonesia termasuk negara peringkat keenam pada tahun 2017 untuk penyakit diabetes melitus terbanyak di dunia setelah RRT, India, USA, Brazil, dan Meksiko jumlah diabetesi dengan umur 20 sampai dengan 79 tahun sejumlah 10,3 juta jiwa.

Laporan Riset Kesehatan Dasar tahun 2018 menunjukkan angka kejadian penyakit DM makin bertambah, dibuktikan dengan penduduk Indonesia sejumlah 6,9\% pada tahun 2013 dan makin meningkat tajam sejumlah $8,5 \%$ pada tahun 2018. Hal ini didukung berdasarkan diagnosis dokter yang menyatakan Diabetes Melitus pada tahun 2018 prevalensi usia yang mengalami penyakit Diabetes Melitus tertinggi yaitu 5564 tahun dengan angka 6,3\%, prevalensi jenis kelamin yang mengalami penyakit Diabetes Melitus tertinggi yaitu perempuan dengan angka 1,8\%, serta prevalensi antara daerah perkotaan dan pedesaan yang mengalami penyakit Diabetes Melitus tertinggi yaitu di daerah perkotaan dengan angka 1,9\% (RISKESDAS, 2018).

Laporan dari Puskesmas Pahandut Kota Palangka Raya diperoleh data bahwa tingkat partisipasi pengelolaan mandiri pasien DM tipe 2 masih rendah penyebabnya adalah pasien cenderung kurang patuh dan kurang menyadari bahayanya penyakit DM. Perilaku perawatan diri diabetes untuk mengontrol kadar glukosanya juga masih rendah sehingga dapat dirumuskan tentang "Bagaimana efikasi diri dan perawatan diri diabetesi?". Tujuan penelitian yaitu menganalisis efikasi diri dan perawatan diri diabetesi di wilayah Puskesmas Pahandut Kota Palangka Raya.

\section{METODE PENELITIAN}

Rancangan penelitian korelasi dengan pendekatan cross sectional. Jumlah sampel 47 responden diabetesi di wilayah kerja Puskesmas Pahandut Kota Palangka Raya, bulan September - Oktober 2019, tehnik sampling consecutive sampling. Instrumen yaitu DMSES (Diabetes Management Self Efficacy Scale) untuk variabel efikasi diri dan SDSCA (Summary of Diabetes Self-Care Activities) untuk variabel perilaku perawatan diri diabetesi. Analisis data univariat untuk mengidentifikasi karakteristik responden dan variabel penelitian, sedangkan bivariat menggunakan Chi Kuadrat untuk mengidentifikasi hubungan efikasi diri dan perilaku perawatan diri dengan tingkat kemaknaan sebesar 0,05.

\section{HASIL}

Data gambaran karakteristik responden mencakup usia, jenis kelamin, pendidikan, pekerjaan, penghasilan, dan lama sakit adalah sebagai berikut. 
Tabel 1

Karakteristik Responden DM Tipe 2 Berdasarkan Usia, Jenis Kelamin, Pendidikan, Pekerjaan, Penghasilan, Dan Lama Sakit Tahun 2019

\begin{tabular}{|c|c|c|c|c|c|}
\hline No. & Karakteristik & Median & Modus & SD & Min-Mak \\
\hline \multicolumn{6}{|c|}{ Usia } \\
\hline \multirow[t]{2}{*}{1} & 56,17 & 57 & 65 & 7,858 & $35-65$ \\
\hline & Jenis Kelamin & & & $\mathrm{n}$ & $\%$ \\
\hline 1 & laki-laki & & & 20 & 42,55 \\
\hline \multirow[t]{2}{*}{2} & Perempuan & & & 27 & 57,45 \\
\hline & Tingkat Pendidikan & & & & \\
\hline 1 & SD & & & 4 & 8.5 \\
\hline 2 & SLTP & & & 11 & 23.4 \\
\hline 3 & SLTA & & & 20 & 42.6 \\
\hline \multirow[t]{2}{*}{4} & PT & & & 12 & 25.5 \\
\hline & Pekerjaan & & & & \\
\hline 1 & PNS & & & 5 & 10.6 \\
\hline 2 & Pensiunan & & & 16 & 34.0 \\
\hline 3 & Wiraswasta & & & 6 & 12.8 \\
\hline \multirow[t]{2}{*}{4} & IRT/tidak bekerja & & & 19 & 42.6 \\
\hline & Penghasilan & & & & \\
\hline 1 & $<$ Rp. 1 juta & & & 20 & 42.6 \\
\hline 2 & Rp. 1 juta - Rp. 5 juta & & & 26 & 55.3 \\
\hline \multirow[t]{2}{*}{3} & $>$ Rp. 5 juta & & & 1 & 2.1 \\
\hline & Lama sakit DM & & & & \\
\hline 1 & 3 bulan s.d. 5 tahun & & & 24 & 51.1 \\
\hline 2 & 6 s.d.10 tahun & & & 15 & 31.9 \\
\hline 3 & 11 s.d.15 tahun & & & 3 & 6.4 \\
\hline 4 & $>15$ tahun & & & 5 & 10.6 \\
\hline
\end{tabular}

Tabel 1 didapatkan umur pasien DM Tipe 2 rata-ratanya adalah 57,40 tahun dengan mayoritas jenis kelaminnya yaitu perempuan sebanyak $57,45 \%$. Mayoritas responden Diabetes Melitus Tipe 2 merupakan tamatan SLTA sebanyak 42,6\%. Mayoritas responden Diabetes Melitus Tipe 2 merupakan ibu rumah tangga atau tidak bekerja berjumlah 42,6\%. Mayoritas responden Diabetes Melitus Tipe 2 mempunyai penghasilan Rp. 1 juta - Rp. 5 juta berjumlah 55,3\%. Sebagian besar responden menderita Diabetes Melitus Tipe 2 antara 3 bulan sampai dengan 5 tahun sebanyak $51,1 \%$.

Tabel 2

Tingkat Efikasi Diri Pasien DM Tipe 2 (Variabel Dependen) Di Wilayah Puskesmas Pahandut Tahun 2019

\begin{tabular}{clcc}
\hline No & Efikasi Diri & $\mathbf{n}$ & $\mathbf{\%}$ \\
\hline 1 & Sangat rendah & 0 & 0 \\
2 & Rendah & 0 & 0 \\
3 & Sedang & 16 & 34 \\
4 & Tinggi & 29 & 61,7 \\
5 & Sangat tinggi & 2 & 4,3 \\
\hline & Total & 47 & 100 \\
\hline
\end{tabular}

Tabel 2 didapatkan sebagian besar responden memiliki efikasi diri tinggi yaitu 61,7\%. 
Tabel 3

Perilaku Perawatan Diri Diabetesi

(Variabel Independen) Di Wilayah Puskesmas Pahandut Tahun 2019

\begin{tabular}{clcc}
\hline No & \multicolumn{1}{c}{$\begin{array}{c}\text { Perilaku Perawatan } \\
\text { Diri }\end{array}$} & n & \% \\
\hline 1 & Sangat rendah & 3 & 6,4 \\
2 & Rendah & 25 & 53,2 \\
3 & Sedang & 6 & 12,8 \\
4 & Tinggi & 5 & 10,6 \\
5 & Sangat tinggi & 8 & 17,0 \\
\hline \multicolumn{2}{r}{ Total } & 47 & 100 \\
\hline
\end{tabular}

Tabel 3 menunjukkan mayoritas responden perilaku perawatan mandiri DM-nya rendah yaitu 53,2\% berdasarkan hasil penelitian tentang perilaku perawatan diri DM pada responden DM Tipe 2.

Tabel 4

Tabulasi Silang Tingkat Efikasi Diri dan Perawatan Diri Diabetesi Di Wilayah Puskesmas Pahandut Tahun 2019

\begin{tabular}{clcccccc}
\hline No & $\begin{array}{c}\text { Tingkat Efikasi } \\
\text { Diri }\end{array}$ & $\begin{array}{c}\text { Sangat } \\
\text { rendah }\end{array}$ & Rendah & Sedang & Tinggi & $\begin{array}{c}\text { Sangat } \\
\text { tinggi }\end{array}$ & Jumlah \\
\hline 1 & Sangat rendah & 0 & 0 & 0 & 0 & 0 & 0 \\
\hline 2 & Rendah & 0 & 0 & 0 & 0 & 0 & 0 \\
\hline 3 & Sedang & 1 & 14 & 1 & 0 & 0 & 16 \\
& & $(6,25 \%)$ & $(87,50 \%)$ & $(6,25 \%)$ & & & $(34,04 \%)$ \\
\hline 4 & Tinggi & 2 & 11 & 5 & 4 & 7 & 29 \\
& & $(6,90 \%)$ & $(37,93 \%)$ & $(17,24 \%)$ & $(13,79 \%)$ & $(24,14 \%)$ & $(61,70 \%)$ \\
\hline 5 & Sangat tinggi & 0 & 0 & 1 & 1 & $2(4,26 \%)$ \\
& & & & & $(50 \%)$ & $(50 \%)$ & \\
\hline & Total & 3 & 25 & 6 & 5 & 8 & 47 \\
& & $(6,38 \%)$ & $(53,19 \%)$ & $(12,77 \%)$ & $(10,64 \%)$ & $(17,02 \%)$ & $(100 \%)$ \\
\hline
\end{tabular}

Tabel 4 menunjukkan bahwa perilaku perawatan diri rendah memiliki efikasi diri sedang sebanyak $87,50 \%$.

Tabel 5

Hasil Uji Chi Kuadrat Efikasi Diri dan Perawatan Diri Diabetesi Di Wilayah Puskesmas Pahandut Tahun 2019

\begin{tabular}{cc}
\hline Nilai Uji Korelasi (r) & $\mathbf{p}$ \\
\hline 17,007 & 0,030
\end{tabular}

Tabel 5 hasil analisis data dengan uji Chi Kuadrat didapatkan ada hubungan positif antara efikasi diri dan perawatan diri diabetesi dengan $\mathrm{p}$ value $=0,030$ dan nilai $r=17,007$.

\section{PEMBAHASAN}

\section{Efikasi Diri Pasien DM Tipe 2}

Hasil penelitian didapatkan data mayoritas pasien Diabetes Melitus Tipe 2 memiliki tingkat efikasi diri tinggi sejumlah $61,7 \%$ dimana responden mempunyai keyakinan diri yang baik terhadap kemampuannya untuk mengatur atau melakukan perilaku gaya hidup sehat. Adanya perbedaan dari lamanya menderita Diabetes Melitus Tipe 2 yaitu rata-rata lama menderita Diabetes Melitus Tipe 2 menyebabkan terjadinya perbedaan efikasi diri pada responden.

Menurut Sarwoko, 2011 menjelaskan bahwa norma subjektif dan efikasi diri 
mempengaruhi intensi seseorang. Makin tinggi dukungan untuk berbuat sesuatu, maka makin tinggi juga niat yang muncul dari dalam dirinya, makin tinggi kepercayaan diri dan kesiapan mental seseorang, maka makin besar juga niatnya untuk melakukan suatu tindakan. Teori Tindakan Beralasan menyatakan proses pengambilan keputusan dan adanya alasan dari suatu tindakan dipengaruhi oleh sikap. Hal ini juga dapat dikatakan bahwa minat untuk melakukan sesuatu dipengaruhi oleh sikapnya sendiri.

Hasil penelitian ini juga didukung oleh Edberg (2010) melalui teori Health Belief Model yang menjelaskan bahwa individu yang telah memperoleh pendidikan kesehatan dan keterampilan untuk perawatan dirinya akan memperoleh persepsi yang baik pula terhadap penyakitnya. sehingga dapat tingkat efikasi dirinya semakin meningkat.

Rias (2016) menyatakan bahwa suatu perilaku kesehatan seseorang dipengaruhi oleh dari dirinya sendiri dan dari luar dirinya, hal ini disebut dengan efikasi diri.

\section{Perilaku Perawatan Diri Pasien DM Tipe} 2

Hasil penelitian didapatkan sebagian besar pederita DM tipe 2 memiliki tingkat perilaku perawatan dirinya dalam 7 (tujuh) hari terakhir, seperti diet, terapi pengobatan, olahraga, pengecekan kadar glukosa, dan perawatan kaki berada pada kategori rendah yaitu 53,2\%. Menurut Suharyat (2009), kekuatan besar dalam menentukan perilaku diperoleh dari individu itu sendiri, seperti motif, nilai, kepribadian, dan faktor lingkungan.

Self-care Diabetes Melitus yang merupakan manajemen perawatan diri pada pasien Diabetes Melitus adalah suatu program yang harus dijalankan oleh diabetesi selama hidupnya secara penuh tanggung jawab. Dengan menekankan upaya pelayanan kesehatan yang berfokus pada peningkatan kesehatan dan pencegahan dengan tanpa mengabaikan upaya pelayanan kesehatan kuratif dan rehabilitatif, pengelolaan termasuk pengendalian faktor risiko Diabetes Melitus dapat mengurangi angka morbiditas dan mortilitas serta komplikasi akut dan kronis akibat dari Diabetes Melitus. Menurut Sutandi tahun 2012 menjelaskan bahwa kontrol DM menjadi lebih optimal apabila ditekankan upaya preventif dengan pengelolaan secara mandiri, baik pada pasien itu sendiri maupun pada keluarga yang merawatnya.

Beberapa aspek dalam selfmanagement diabetes dapat memengaruhi kadar gula darah, seperti pengaturan pola makan yang berfungsi untuk menekan asupan karbohidrat, lemak yang berlebih agar kadar glukosa dalam darah dapat seimbang dengan kerja hormon insulin, aktivitas fisik/olahraga membantu dalam pengaturan kontrol BB, sehingga gula darah dibakar menjadi kalori dalam tubuh yang menyebabkan sel tubuh lebih sensitif terhadap hormon insulin yang diproduksi oleh sel beta dalam kelenjar pankreas, perawatan diri/kaki dapat membantu menjaga kesehatan kaki serta meminimalisir risiko timbulnya luka kaki pada pasien Diabetes Melitus yang dapat berkembang menjadi ulkus diabetik, kandungan yang terdapat pada obat antidiabetik seperti jenis obat derivate sulfonilurea dapat membantu penyerapan glukosa dalam darah serta jenis biguanida untuk menghambat proses pembentukan glukosa, sedangkan perilaku monitoring gula darah rutin dapat digunakan sebagai acuan untuk menilai keberhasilan dari penanganan diabetes yang telah dilakukan, dan dapat dijadikan sebagai motivasi diabetesi untuk mengendalikan kadar glukosa darahnya di dalam rentang yang normal.

\section{Hubungan Efikasi Diri dan Perilaku Perawatan Diri pada Diabetesi}

Dari hasil penelitian diperoleh data bahwa tingkat efikasi diri berdasar perilaku perawatan diri diabetesi sebagian besar dalam kategori efikasi diri sedang dan perawatan 
diri yang rendah sejumlah $87,50 \%$. Hasil uji Chi Kuadrat nilai $\mathrm{p}=0,030$ dan nilai $\mathrm{r}=$ 17.007 menunjukkan terdapat hubungan yang linier efikasi diri dan perilaku perawatan diri pasien Diabetes Melitus Tipe 2.

Menurut Ariyani, dkk tahun 2012 menjelaskan terdapat hubungan efikasi diri dengan motivasi dan dukungan keluarga. Dengan hasil ini perawat direkomendasi untuk memberikan dukungan pada diabetesi dengan memberikan penyuluhan atau pemberian informasi secara terstruktur dan dukungan sosial.

Penelitian Wira tahun 2018 menjelaskan bahwa untuk mencegah komplikasi akut dan kronis yang diakibatkan oleh DM Tipe 2 dapat dilakukan dengan manajemen perawatan secara mandiri oleh diabetesi. Rendahnya tingkat efikasi diri seseorang dan kurangnya dukungan sosial merupakan faktor-faktor penghambat pengelolaan perawatan diri.

Motivasi adalah faktor yang sangat penting bagi pasien Diabetes Melitus dalam hal mempertahankan diet dan pemantauan gula darah untuk melakukan perilaku perawatan secara mandiri. Mencapai tujuan yang diinginkan dalam hal pengontrolan gula darah, diabetesi yang mempunyai efikasi diri yang baik terhadap kemampuannya untuk mengatur gaya hidup sehat akan mampu melakukan perilaku perawatan diri yang baik pula untuk penanganan Diabetes Melitus.

\section{KESIMPULAN}

Efikasi diri dan perawatan diri diabetes memiliki hubungan yang signifikan, sehingga adanya pendekatan perilaku dapat mengurangi komplikasi dan mengoptimalkan kualitas hidup.

\section{DAFTAR PUSTAKA}

Ariani Y., dkk. (2012). Motivasi dan efikasi diri pasien DM tipe 2 dalam asuhan keperawatan. Jurnal Keperawatan Indonesia, 15(1), 29-38.
Cataloguing, W. L. (2016). Global Report on Diabetes. Isbn, 978, 6-86. http://www.who.int/about/licensing/c opyright_form/index.html.

Funnell, et al (2008). National standards for diabetes self-management education. Diabetes Care, 31. (SUPPL. 1), S97S104. https://doi.org/10.2337/dc08$\underline{\text { S097. }}$

Indonesia, K. K. R. (2018). Hasil utama riskesdas 2018. Jakarta: Badan Penelitian dan Pengembangan Kesehatan.

Perkeni. (2015). American families and absences: Breaking the parent-child bond. Dissertation Abstracts International Section A: Humanities and Social Sciences, 71(2-A), 730. https://doi.org/10.1017/CBO9781107 415324.004 .

Manuntung, A. (2018). Analisis Keyakinan Diri Pasien Diabetes Mellitus Tipe 2 Dalam Pengelolaan Diabetes Mellitus. Jurnal Kesehatan Manarang, $3(1), \quad 31$. https://doi.org/10.33490/jkm.v3i1.32.

(2019). Monitoring Gula Darah Mandiri dan Perawatan Kaki Diabetik di Wilayah Kerja Puskesmas Pahandut. Jurnal Pengabdian Masyarakat Borneo, 3(2), 25-30.

Ri, K. (2018). Profil Kesehatan Indonesia Tahun 2017. Jakarta: Kementerian Kesehatan RI, 170-173.

Rias, Y. A. (2016). HUBUNGAN PENGETAHUAN DAN KEYAKINAN DENGAN EFIKASI DIRI PENYANDANG DIABETIC FOOT ULCER. 1(1). 
Adi Husada Nursing Journal, Vol 6 No 1, Juni 2020/ Hal. 58

Sarwoko, E. (2011). Kajian Empiris Entrepreneur Intention Mahasiswa. 2.

Sutandi, A. (2012). Self Manajemen Education (DSME) sebagai Metode Alternatif dalam Perawatan Mandiri Pasien Diabetes Melitus di dalam Keluarga. Widya, 29(321), 47-52.
WHO. (2016). Global report on diabetes: executive summary (No. WHO/NMH/NVI/16.3). WHO.

Wira, P., \& Putra, K. (2018). HUBUNGAN SELF EFFICACY DAN DUKUNGAN SOSIAL TERHADAP. 3(1), 51-59. 